The Editors of the Proceedings of The Nutrition Society accept no responsibility for the abstracts of papers read at the Society's meetings for original communications. These are published as received from the authors.

\title{
ABSTRAGTS OF GOMMUNICATIONS
}

The One Hundred and Thirtieth Meeting of The Nutrition Society (Fifty-seventh of the Scottish Group) was held in Adam House (University of Edinburgh), Chambers Street, Edinburgh, on Saturday, 27 February 1960, at 2 p.m., when the following papers were read:

Calcium deficiency in rats fed upon meat. By T. Moore and I. M. Sharman, Dunn Nutritional Laboratory, University of Cambridge and Medical Research Council

Bland-Sutton (I889) observed skeletal fractures in carnivora kept in captivity and fed upon lean meat. These abnormalities could be prevented by the addition of crushed bones and cod-liver oil to the diet. Recently Greaves, Scott \& Scott (1959) have observed softening of the bones in cats fed upon ox heart. The lesions were presumably caused by the low calcium content of the heart meat, since they could be prevented by the inclusion of calcium in the diet. In view of the possible relevance of these observations to human dietetics we thought it desirable to make similar studies on some omniverous animal, and this note deals with our findings on rats.

Diets were composed of three parts of raw lean ox heart or ox skeletal muscle minced up with one part of ox depot fat. This ratio between lean and fat was intended to typify untrimmed meat as usually supplied by the butcher. Adequate doses of vitamin A were given. Other rats received the same diet fortified with $0.5 \%$ of calcium carbonate, or with doses of 200 i.u. vitamin D weekly, or with both these supplements combined.

The animals given diets without calcium or vitamin D usually stopped gaining weight after about 30 days, and all had died, or had become emaciated and feeble, within 80 days. In all the rats the bones became soft and had reduced opacity to $\mathrm{X}$-rays. Deformities or fractures in the ribs and hind legs were common. Haemorrhage sometimes occurred, particularly intramuscularly in the hind legs. Administration of vitamin $\mathrm{D}$ alone had no beneficial effect, apart possibly from a temporary improvement in weight gains. The inclusion of calcium in the diet, either with or without vitamin D, prevented both the failure in growth and the skeletal abnormalities. Rats fed upon lean meat without added fat were not immune from skeletal abnormalities, but these tended to be less severe than in rats given fat. The rats not given fat eventually reached higher body-weights than those receiving fat, and the incidence of deaths was lower.

These experiments confirm the finding that the injurious effect of a meat diet on the bones is due to lack of calcium, and indicate that the lesions are not confined to carnivora. When part of the lean meat is replaced by food which presumably contains even less calcium, such as fat, the skeletal lesions are intensified. 
The effect of environmental temperature on the energy metabolism of steers. By K. L. BLAXTER and F. W. WAINMAN, Hannah Dairy Research Institute, Kirkhill, Ayr

Two Aberdeen Angus Cross steers were given rations of hay and oats sufficient to maintain them. Measurements of their energy exchange and a partition of their heat losses were then made at environmental temperatures of $-5,4,15,25$ and $35^{\circ}$.

Four further experiments with the same animals given a submaintenance ration of hay were made at environmental temperatures of -5 and $20^{\circ}$. The experiments were carried out in a closed-circuit respiration chamber in which the walls and circulating air stream were cooled or heated by circulating brine. Each experiment lasted at least 4 days and exposure to the environment was continuous throughout these periods.

The results showed that environmental temperature had small effects on the faecal energy loss and the loss of energy as methane but none on the loss of energy as the heat of combustion of the urine solids. Heat production increased when environmental temperature was reduced below $7^{\circ}$. The energy retentions of the steers at the different environmental temperatures determined by calorimetric measurements as well as from balances of carbon and nitrogen are given in the table. They show large falls in energy retention at environmental temperatures of -5 , and $4^{\circ}$. A marked fall in energy retention at $35^{\circ}$ occurred in steer Amos which was very uncomfortable in hot conditions.

Retention of energy $(k c a l / 24 h)$ by two steers receiving $23000 \mathrm{kcal}$ dietary energy/24 $h$ at different environmental temperatures

$\begin{array}{ccc}\begin{array}{c}\text { Environmental } \\ \text { temperature }\end{array} & \text { Steer } & \text { Steer } \\ \left({ }^{\circ} \mathrm{C}\right) & \text { Amos } & \text { Andy } \\ -5 & -1898 & -3169 \\ +4 & -648 & -1891 \\ +15 & +377 & -152 \\ +25 & +51 \mathrm{r} & -82 \\ +35 & -598 & -159\end{array}$

Studies of the heat emission showed that losses of heat per unit surface by convection, conduction and radiation were unaffected by the level of nutrition. The total thermal conductances of the steers below their critical temperature, that is when completely vasoconstricted were $50.6 \pm 0.7$ and $48 \cdot 1 \pm 0.5 \mathrm{kcal} / \mathrm{m}^{2} / 24 \mathrm{~h} /{ }^{\circ} \mathrm{C}$ for steer Amos and steer Andy respectively. Values for sheep with fleeces of comparable length $(8 \mathrm{~mm})$ to the hair coat of the steers were $50.3 \mathrm{kcal} / \mathrm{m}^{2} / 24 \mathrm{~h} /{ }^{\circ} \mathrm{C}$ (Blaxter, Graham \& Wainman, 1959; Armstrong, Blaxter, Clapperton, Graham \& Wainman, 1960), suggesting that cattle and sheep differ little in the insulation that their coats and cutaneous tissues provide. 
Blaxter, K. L., Graham, N. McC. \& Wainman, F. W. (1959). Y. agric. Sci. 52, 41.

Armstrong, D. G., Blaxter, K. L., Clapperton, J. L., Graham, N. McC \& Wainman, F. W. (r960). Unpublished data.

The effect of muscular work on the energy metabolism of sheep. By J. L. Clapperton, D. G. Armstrong and K. L. Blaxter, Hannah Dairy Research Institute, Kirkhill, Ayr

Two sheep were each given rations of dried grass at either the maintenance level of nutrition (two experiments), a submaintenance level (one experiment) or in amounts which resulted in considerable fat storage (two experiments). In each of the ten experiments metabolism was measured in $24 \mathrm{~h}$ periods for $\mathrm{I} 2$ days using a closedcircuit respiration apparatus. During the $5^{\text {th }}$ to 8 th days inclusive, the sheep walked up a gradient on a treadmill in the respiration chamber for varying times. These times were adjusted on the basis of body-weight so that each sheep performed constant work from experiment to experiment. The distance travelled per day was at maximum 7.8 miles and the height ascended $244^{\circ} \mathrm{ft}$. Four further experiments were made during starvation when the same amount of exercise was given on the 3 rd and

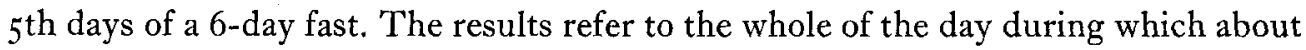
$4 \mathrm{~h}$ of exercise was performed, that is, they include any compensatory reduction in muscular activity in the $20 \mathrm{~h}$ following exercise.

The results showed that the faecal loss of energy was not significantly altered by exercise. Methane production increased slightly and significantly from $27 \cdot 8$ to $28 \cdot 7$ $1 . / \mathrm{kg}$ food dry matter, but the metabolizable energy of the ration was not significantly affected. Heat production was determined from the non-protein respiratory quotient and oxygen consumption and also from changes in the body retention of carbon and nitrogen. The increases in heat production on days of exercise compared with days on which the sheep rested declined during the 6 months of experiment by about $30 \%$ both at the maintenance level of feeding and during fasting. This was probably due to increased familiarity of the sheep with experimental conditions rather than to their 'training' in the sense this term is used in athletics. The increments of heat determined at maintenance and at fasting differed by $4 \%$, fasting being lower, but the difference was not statistically significant. During fattening, the increments of heat associated with muscular work were $17 \%$ less than at maintenance, and this difference was statistically significant (odds $30: 1$ ). The heat increments of the metabolizable energy of the ration in the unexercised animals were, below maintenance, $23 \%$ and above maintenance, $47 \%$. The reduction in the apparent cost of work in fattening sheep can therefore be interpreted as a diversion of nutrients from lipogenesis to oxidation. 
The effect of including stabilized tallow in the concentrate mixture fed to early-weaned calves. By 'T. R. Preston, F. G. Whitelaw, R. D. Ndumbe and Euphemia B. Charleson, Rowett Research Institute, Bucksburn, Aberdeen

Twenty male and sixteen female Angus Cross calves, paired according to sex and date of birth, were reared to 3 months of age on the early-weaning system described by Preston, MacLeod \& Dinda (I959). Within pairs, calves were allocated at random to a 'control' early-weaning concentrate or to a similar concentrate supplemented with $5 \%$ of stabilized tallow.

The increases in the body measurements--chest girth, wither height and length and width of pelvis-were significantly greater for calves given the ration containing tallow (Table I). There were no differences in food consumption between the groups of calves fed the two rations.

Table I. Effect of adding 5\% of stabilized tallow to the concentrate mixture given to early-zeaned calves

Measurement from 3 to 84 days of age

$$
\text { Daily }\left\{\begin{array}{l}
\text { Live weight (lb/day) } \\
\text { Chest gitth (cm/day) } \\
\text { Height at withers (cm/day) } \\
\text { Width of pelvis (cm/day) } \\
\text { Length of pelvis (cm/day) }
\end{array}\right.
$$

Concentrate consumption $(\mathrm{kg})$

Dried-grass consumption $(\mathrm{kg})$

* Significant difference, $\mathrm{P}<0.05$.
Mean within-pair difference (tallow - control)

Value s.e.

$+0.10 \quad \pm 0.06$

$+0.026 * * \quad \pm 0.009$

$+0.019^{* *} \quad \pm 0.006$

$+0.010^{*} \quad \pm 0.004$

$+0.007^{*} \quad \pm 0.003$

$+0.8 \quad \pm 6.4$

$-1 \cdot 3 \quad \pm 2 \cdot 4$

** Significant difference, $\mathrm{P}<0 \cdot 0 \mathrm{r}$.

The two diets were also fed alternately to each of six Ayrshire male calves in metabolism crates. A double-reversal feeding plan was used during three consecutive IO-day experimental periods each consisting of 5 days preliminary and five days collection. Feeding was kept constant during each experimental period at a level of $80 \mathrm{~g}$ air-dry food per unit of metabolic live weight $\left(\mathrm{kg}^{0.74}\right)$ adjusted to the live weight of the calf at the beginning of each period.

There were no significant differences between the two diets in dry-matter digestibility or in nitrogen retention per unit metabolic live weight, but there was an indication that, for each calf, gain in live weight, and to a lesser extent nitrogen retention, increased when the changeover was from the tallow to the control diet and decreased when the changeover was from control to tallow.

\section{REFERENCE}

Preston, T. R., MacLeod, N. A. \& Dinda, P. K. (1959). Anim. Prod. 1, 13.

The effect of glucose introduced into the abomasum and rumen on the utilization of casein administered orally to sheep. By MARGARET I. Chalmers and J. M. OGilvie, Rowett Research Institute, Bucksburn, Aberdeen The addition of easily fermentable carbohydrate to a normal feed for the ruminant may have a direct effect of conserving protein in the intestinal tract independent of 
any parallel effect which the ratio of protein to carbohydrate intake may have on the nitrogen balance of the animal as a whole.

In an experiment where the basal diet gave zero $\mathrm{N}$ balance, ewes received a daily supplement of $50 \mathrm{~g}$ casein by mouth; the marginal apparent retention of nitrogen from the casein was $24 \%$. The administration of $50 \mathrm{~g}$ glucose/day by ruminal fistula increased the percentage $\mathrm{N}$ retained from the casein whereas administering the glucose by abomasal fistula gave no protein-sparing effect.

The casein and glucose supplements administered together by abomasal fistula showed a retention of $62 \%$ of the casein N. Earlier Chalmers, Cuthbertson \& Synge (1954) obtained $48 \%$ retention from casein administered by duodenal fistula; the increase in retention from the addition of glucose is similar to the protein-sparing effect observed in monogastric animals.

In a ruminant the addition of easily fermentable carbohydrate to a feed seems to have a direct effect on conserving protein in the rumen.

\section{REFERENCE}

Chalmers, M. I., Cuthbertson, D. P. \& Synge, R. L. M. (r954). F. agric. Sci. 44, 254.

A nutritional study of three common fats of the Pakistani dietary. By

D. J. Naismith and Rahmat U. QuReshi, Human Nutrition Research Unit, Nutrition Building, National Institute for Medical Research, London, N.W.7

The per capita consumption of food in Pakistan comprises about $2150 \mathrm{kcal} /$ day and $50 \mathrm{~g}$ protein, $84 \%$ of which is derived from plant products (FAO, 1958).

Since the diet contains only $2.3 \%$ fat, an increase in the consumption of calories, and consequently an improvement in protein utilization, might best be achieved by addition of fat to the diet.

In view of the suspected relationship between the consumption of fat, serumcholesterol levels and atherosclerosis in man, the choice of fat would have to be determined by clinical as well as economic considerations.

The three fats most commonly used in the Pakistani dietary, ghee, hydrogenated cottonseed oil and mustard-seed oil, were chosen for study. To a basal Pakistanitype diet each fat was added separately to make up either $2.3 \%$ or $16 \%$ of the total weight. Seventy-two male albino rats were used, weighing approximately $40 \mathrm{~g}$. Three groups of twelve animals were fed the high-fat diets $a d$ lib.; to the remaining three groups, the low-fat diets were fed at levels restricting calorie intake to $70 \%$ of the corresponding high-fat groups. In this way, protein intake was identical at both calorie levels. Blood was drawn from each animal at the end of 12 weeks, and livers were removed, for cholesterol determinations.

\section{Influence of quality and quantity of dietary fat on serum cholesterol in the rat}

Ghee

Dietary fat

Hydrogenated cottonseed oil

Mustard-seed oil

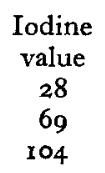

$\begin{array}{cc}\text { Total serum cholesterol (mg/roo ml) } \\ \text { Low-fat diet } & \text { High-fat diet } \\ 92 & 100 \\ 91 & 95 \\ 102 & 117\end{array}$ 
Consumption of both ghee and mustard-seed oil at the higher level promoted a significant rise in serum cholesterol $(P=0.05 ; P<0.02)$. Addition of hydrogenated cottonseed oil to the diet, however, had no significant effect.

The serum-cholesterol levels of the rats receiving the unsaturated mustard-seed oil were considerably higher than those of the rats fed either of the other two fats, irrespective of the amount of fat in the diet. These differences were statistically highly significant $(P<0.00 \mathrm{I} ; P<0.0 \mathrm{I})$. Liver cholesterol was also raised by the feeding of mustard-seed oil at the higher level $(P<0.01)$. The factor responsible for these changes in cholesterol content is believed to be erucic acid (see Carroll, r959), which constitutes $42 \%$ of the fatty acids of mustard-seed oil.

\section{REFERENCES}

Carroll, K. K. (1959), Canad. F. Biochem. Physiol. 37, 803. FAO (1958). Prod. Yearb. 12, 239.

Further studies on the administration of chromium sesquioxide as a component of paper. By J. L. Corbett, G. W. Reid, J. P. Langlands and E. FLORENCE, Rowett Research Institute, Bucksbum, Aberdeen

It has been shown (Corbett, Greenhalgh \& MacDonald, 1958; Corbett, Greenhalgh, McDonald \& Florence, I 960$)$ that when doses of chromium sesquioxide $\left(\mathrm{Cr}_{2} \mathrm{O}_{3}\right)$ are administered to sheep as a component of a specially made paper containing $35-40 \%$ $\mathrm{Cr}_{2} \mathrm{O}_{3}$ in the dry matter, instead of in gelatin capsules, the $\mathrm{Cr}_{2} \mathrm{O}_{3}$ is cleared much more slowly and regularly from the reticulo-rumen and is excreted more evenly in the faeces.

In a grazing trial $\mathrm{Cr}_{2} \mathrm{O}_{3}$ was administered twice daily in a gelatin capsule to each of three cattle, and as a component of paper, shredded into strips about $2 \times 120 \mathrm{~mm}$, to a further three similar cattle. Faeces voided on the pasture were identified by the presence of the distinctively coloured polystyrene particles which were administered regularly to each animal. By this means numbers of faeces samples varying from six to thirteen were obtained from each animal on each of 3 days.

Variability, expressed as coefficients of variation, in the concentration of $\mathrm{Cr}_{2} \mathrm{O}_{3}$ in the organic matter of the several samples of faeces (numbers in parentheses) obtained on each of 3 days from each of six grazing cattle

\begin{tabular}{ccccr} 
Form of & Animal & \multicolumn{3}{c}{ Coefficient of variation (\%) } \\
$\mathrm{Cr}_{2} \mathrm{O}_{3}$ doses & no. & Day 1 & Day 2 & Day 3 \\
Paper & $I$ & $8 \cdot 8(10)$ & $18 \cdot 5(13)$ & $14.7(10)$ \\
& 2 & $5 \cdot 4(9)$ & $12 \cdot 0(9)$ & $7 \cdot 2(10)$ \\
Capsules & 3 & $10.8(8)$ & $5.9(8)$ & $7.0(8)$ \\
& 4 & $13.3(9)$ & $13.4(9)$ & $24.4(9)$ \\
& 5 & $14.2(8)$ & $14.5(9)$ & $15.5(6)$ \\
& 6 & $20.8(12)$ & $6.3(12)$ & $10.0(11)$
\end{tabular}

Variability in concentration itself varied significantly from day to day as is to be expected under grazing conditions (Corbett, Greenhalgh, Gwynn \& Walker, 1958). 
Between treatments, on average the variability was significantly less $(P<0.05)$ for animals given $\mathrm{Cr}_{2} \mathrm{O}_{3}$ in paper form.

In further experiments cattle in metabolism stalls were fed standard quantities of fresh herbage of progressively increasing maturity and declining digestibility cut daily from a single sward. The percentage recovery of $\mathrm{Cr}_{2} \mathrm{O}_{3}$ in faeces, virtually complete when the feed is of constant composition, in this case appeared to decline progressively whether the $\mathrm{Cr}_{2} \mathrm{O}_{3}$ was administered in the paper or in capsules. This phenomenon may be due to a decline in the rate of passage of digesta through the gut and is receiving further study.

\section{REFERENCES}

Corbett, J. L., Greenhalgh, J. F. D., Gwynn, P. E. \& Walker, D. (1958). Brit. Ұ. Nutr. 12, 266.

Corbett, J. L., Greenhalgh, J. F. D. \& MacDonald, A. P. (1958). Nature, Lond., I82, 1o14.

Corbett, J. L., Greenhalgh, J. F. D., McDonald, I. \& Florence, E. (1960). Brit. $\mathscr{Y}$. Nutr. $14,289$.

The occurrence of phosphates of calcium on cobalt oxide 'bullets' administered to lambs to prevent pining. By E. C. OWEN, Hannah Dairy Research Institute, Kirkhill, Ayr, S. E. ELLIS, Mineralogy Department, British Museum (Natural History), London, S.W.7, R. C. Voss, Spectrographic Unit, West of Scotland Agricultural College, Auchincruive, Ayr, and A. L. WILson and J. RoBERTSON, Veterinary Investigation Department, West of Scotland Agricultural College, Auchincruive, Ayr

Dewey, Lee \& Marston (1958) have reported the use of pellets made of a lightly baked mixture of cobalt oxide and a clay (bentonite), for supplying cobalt slowly but continuously to lambs in areas where pining due to cobalt deficiency is enzoötic. Dewey et al. (1958) found that in some animals, so treated, the 'bullet' became encrusted with a whitish deposit and suggested that the material composing the crust was brushite $\left(\mathrm{CaHPO}_{4} \cdot 2 \mathrm{H}_{2} \mathrm{O}\right)$. We have examined a number of such encrusted bullets obtained in 1958 from the reticulo-rumen of lambs at slaughter in the west of Scotland. By chemical, optical and spectrographic methods we have found that the incrustations contain brushite and whitlockite $\left(\mathrm{Ca}_{3}\left(\mathrm{PO}_{4}\right)_{2}\right)$ as their main constituents and other minor constituents. They thus resemble in composition certain urinary calculi (Prien \& Frondel, r947), salivary calculi (Leung \& Jensen, 1958) and dental tartar (Leung \& Jensen, 1958). Brushite is a normal constituent of guano (Dana \& Ford, I 922). Thus all the places where these phosphates are found are places where ammonia may be produced from other compounds of nitrogen. It is probable that at each site bacteria are responsible for the ammoniogenesis and that the ammonia produced causes the $\mathrm{pH}$ to rise to between 7 and 8 so allowing brushite and whitlockite to be deposited, together with traces of struvite $\left(\mathrm{MgNH}_{4} \mathrm{PO}_{4} \cdot 6 \mathrm{H}_{2} \mathrm{O}\right)$, i.e. magnesium ammonium phosphate hexahydrate.

Photographs and samples of the materials will be shown at the meeting.

A detailed account of this investigation is in preparation for the press. 
Dana, E. S. \& Ford, W. E. (1922). Textbook of Mineralogy. London: Chapman \& Hall. Dewey, D. W., Lee, H. J. \& Marston, H. R. (1958) Nature, Lond., 181, 1367. Leung, S. W. \& Jensen, A. T. (1958). Int. dent. F. 8, 6 I $3 .^{3}$ Prien, E. L. \& Frondel, C. (1947). F. Urol. 57, 949.

\section{The mechanism by which administration of individual amino acids causes changes in the ribonucleic-acid metabolism of the liver. By $H$. N. Munro and D. MukerjI, Department of Biochemistry, University of Glasgow} Previous studies (Munro \& Mukerji, I958) have shown that the feeding of certain amino acids to rats can cause an increase in the amount of ${ }^{32} \mathrm{P}$ incorporated by the ribonucleic acid (RNA) of the liver. Significant increments were obtained after giving glycine, methionine and leucine. In the present experiments we have explored the mechanism underlying the action of these three amino acids.

Glycine, L-methionine and L-leucine were fed singly in I $\mathrm{g}$ doses to rats and the animals were killed $\mathrm{r} 8 \mathrm{~h}$ later. The expected increment in ${ }^{32} \mathrm{P}$ uptake by liver RNA was observed. It was shown to be accompanied by an increase in the amount of protein in the liver. In view of previous work on the relationship between protein synthesis and RNA metabolism in the liver (Clark, Naismith \& Munro, 1957), this suggests that the change in ${ }^{32} \mathrm{P}$ uptake by RNA after administration of these amino acids is secondary to an increase in liver protein synthesis.

When the glycogen content of the liver was measured i $8 \mathrm{~h}$ after administration of each amino acid, it was found to be raised. Deposition of protein and glycogen in the liver is characteristic of increased adrenocortical activity. Experiments were therefore carried out to test this interpretation of the action of the three amino acids.

First, it was shown that the administration of cortisone ( $5 \mathrm{mg} / 100 \mathrm{~g}$ body-weight) to rats maintained under our experimental conditions caused an increment in ${ }^{32} \mathrm{P}$ uptake by liver RNA. Secondly, it was shown that the level of corticosterone in the plasma of the rat rose after the feeding of glycine, methionine or leucine. Finally, rats were subjected to adrenalectomy and were then fed with the three amino acids individually. The feeding of methionine or leucine to these animals failed to increase uptake of ${ }^{32} \mathrm{P}$ by liver RNA and there was no deposition of glycogen in the liver. Adrenalectomy also abolished the deposition of glycogen produced by feeding glycine, but the effect of glycine on ${ }^{32} \mathrm{P}$ incorporation into RNA, though diminished, was not wholly eliminated. Consequently, glycine affects liver RNA metabolism through another mechanism in addition to its effect on adrenocortical activity.

These observations show that some at least of the amino-acids contained in dietary proteins influence the secretory activity of the adrenal cortex and through it the distribution of amino acids between carcass and viscera (Goodlad \& Munro, 1959). The effect of the protein content of the diet on adrenocortical composition is discussed in the next communication (Hutchison, Ramaiah, Neilson \& Munro, 1960).

\section{REFERENCES}

Clark, C. M., Naismith, D. J. \& Munro, H. N. (1957). Biochim. biophys. Acta, 23, 587.

Goodlad, G. A. J. \& Munro, H. N. (1959). Biochem. F. 73, 343. 
Hutchison, W. C., Ramaiah, T. R., Neilson, F. J. \& Munro, H. N. (rg6o). Proc. Nutr. Soc. r9, xxiii. Munro, H. N. \& Mukerji, D. (1958). Biochem. F. 69, 32 r.

The influence of diet on the protein, nucleic-acid and phospholipid content of the adrenal gland. By W. C. Hutchison, T. R. Ramaiah, Frances J. Neilson and H. N. Munro, Department of Biochemistry, University of Glasgow The preceding communication (Munro \& Mukerji, rg60) showed that the feeding of certain amino acids stimulates the activity of the adrenal cortex. Thus the dietary protein level may affect adrenocortical function. Early work on the effect of variation in the protein level of the diet on the adrenal gland yielded somewhat contradictory results (Tepperman, Engel \& Long, r943; Ingle, Ginther \& Nezamis, 1943; Benua \& Howard, 1945; Ingle, 1945). It seemed desirable, therefore, to reinvestigate the effect of different diets on adrenal size and composition, and on sensitivity to adrenocorticotrophic hormone (ACTH).

The diets used contained either an adequate level of protein or no protein. At each level of protein intake the energy content of the diet was varied, some animals receiving no energy supplement, other $5 \mathrm{~g}$ carbohydrate, and others an isocaloric amount of olive oil. In this way six different diets were used. Adequate vitamins, minerals and roughage were included in all cases.

The six diets were fed to mature female albino rats for periods of 5 or II days. During the last 3 days ACTH (Cortrophin-ZN, Organon) was administered to half of the animals at a level of $\mathrm{ro} \mathrm{mg} /$ day/rat in two equal doses, morning and evening. The results show that protein deficiency causes a significant depression in gland weight, in the total amount of phospholipid and ribonucleic acid (RNA) in the gland, and, in the longer experiments, in the amount of deoxyribonucleic acid (DNA). In these longer experiments a reduction in the total protein content of the gland was also observed, but failed to reach significance. The different energy levels did not, under these conditions, affect significantly either the gland weight or the constituents measured.

The response of the gland to ACTH is uninfluenced by the protein or energy content of the diet. Increases, significant at the $1 \%$ level, are obtained in gland weight and in all the constituents measured except in the case of DNA, which does not change. Examination of the composition of the additional tissue deposited under the influence of ACTH shows that it is richer in RNA and protein than is normal adrenal, but that it is poorer in phospholipid.

These results suggest that protein deficiency, while not affecting the ability of the adrenal to respond to ACTH, nevertheless produces impaired adrenal activity.

\section{REFERENCES}

Benua, R. S. \& Howard, E. (1945). Endocrinology, 36, 170.

Ingle, D. J. (1945). Endocrinology, 37, 7.

Ingle, D. J., Ginther, G. B. \& Nezamis, J. (1943). Endocrinology, 32, 4ro.

Munro, H. N. \& Mukerji, R. (1960). Proc. Nutr. Soc., rg, xxii.

Tepperman, J., Engel, F. L. \& Long, C. N. H. (1943). Endocrinology, 32, 403. 
The One Hundred and Thirty-third Meeting of The Nutrition Society was held at St. Thomas's Hospital Medical School, London, S.E.I, on Saturday, 2 I May ig6o, when the following papers were read:

\section{Cholesterol concentration in plasma and organs of rats given thrombo-} genic and atherogenic diets. By A. N. Howard, Dunn Nutritional Laboratory, University of Cambridge and Medical Research Council, and G. A. Gresham, Department of Pathology, University of Cambridge

Much recent work on the nature of coronary heart disease in man has been confined to estimations of plasma cholesterol. It has been assumed that a high plasma cholesterol is causally related to an increased severity of atherosclerosis and therefore of coronary heart disease. Gresham \& Howard (in preparation) found that a diet for rats devised by Thomas \& Hartroft (1959) containing 40\% butter, $5 \%$ cholesterol, $2 \%$ cholic acid and $0.3 \%$ thiouracil (group I) produced myocardial and renal infarction, and thrombosis of the thoracic aorta, coronary arteries, ventricles, atria and renal veins. Substitution of $40 \%$ arachis oil (group 2) for $40 \%$ butter produced neither infarction nor thrombosis. In contrast, extensive atherosclerosis similar to that seen in man occurred in the thoracic aorta and coronary arteries. It was concluded that thrombosis and atherosclerosis were two independent phenomena. The investigations reported here are concerned with cholesterol concentration in plasma and organs of the two groups of animals.

Groups of ten male rats were given the two above-mentioned diets for 3 months and then killed; a control group was given a diet, containing $10 \%$ arachis oil but no cholesterol, cholic acid or thiouracil (group 3). As expected, animals in groups I and 2 had greatly increased cholesterol in the plasma, liver and spleen compared with controls. Animals given the diet containing $40 \%$ butter had the highest mean plasma cholesterol (group I, 3.48; group 2, 2.19; group 3, $0.21 \mathrm{~g} / \mathrm{100} \mathrm{ml}$ ). Those given $40 \%$ arachis oil had the highest mean liver cholesterol (group I, 9.3; group 2, $\mathrm{r} 4 \cdot \mathrm{I}$; group 3,0.72 $\mathrm{g} / 100 \mathrm{~g}$ ) and mean spleen cholesterol (group I, 2.22; group 2, $3.10 ;$ group $3,0.77 \mathrm{~g} / \mathrm{I00} \mathrm{g}$ ). Atherosclerotic plaques occurred only in group 2 ; they could not be analysed but were shown to have a high cholesterol content by the Schultz method.

It was concluded that in these rats plasma cholesterol is not necessarily an index of the severity of atherosclerosis and that experiments involving only the determination of plasma cholesterol are of limited value. Since butter differs from arachis oil in having a high content of saturated fatty acids and a low content of essential unsaturated fatty acids, the results support the hypothesis that saturated fats are thrombogenic. Essential unsaturated fatty acids may, however, facilitate the deposition of cholesterol in the tissues and the production of atherosclerosis.

\section{REFERENCE}

Thomas, W. A. \& Hartroft, W. S. (1959). Circulation, r9, 65. 
Determination of gastric-acid secretion using a resin-dye complex. By A. Nelson-Smith (introduced by A. E. Bender), Research Department, Bovril Ltd, $x_{4} 8$ Old Street, London, E.C.I

The use of carboxylic cation-exchange resins impregnated with dyes or indicators to detect gastric-acid secretion was introduced by Segal, Miller \& Morton ( 1950 ). The technique avoids intubation or surgery and depends on the liberation of the dye by the acid in the stomach and its subsequent excretion in the urine.

Our preliminary results suggest that the method can be used to measure acid secretion quantitatively in the rat.

Azur A dye was adsorbed on Amberlite IRC-50H resin. The resin was mixed into the diet to about $6 \%$. Rats, which had been fasted before the experiment, were fed the resin diet once daily. Urine was collected for at least $15 \mathrm{~h}$ after the meal and its optical density (O.D.) determined in the spectrophotometer at $640 \mathrm{~m} \mu$.

The results were calculated as an Index of Gastric Acidity $=$

$$
\frac{\text { O.D. } \times \text { vol of urine }(\mathrm{ml})}{\text { food eaten }(\mathrm{g})} \text {. }
$$

When stock diet (Thomson diet) was fed the normal gastric-acid secretion caused the appearance of dye in the urine and this index was taken as the normal level. The normal acid secretion of an individual rat (as indicated by dye in the urine) can vary widely at different periods and, therefore, control and experimental diets were fed on alternate days.

The experimental diets consisted of stock diet with the addition of gastric secretory stimulants such as meat extract, ethanol and histamine. All these materials produced increased acid secretion, the increase being proportional to the amount of stimulant added, up to a maximum level.

Other cations, in the concentration normally met in the intestines, do not interfere and both the resin and the dye appear to be physiologically inert.

\section{REFERENCE}

Segal, H. L., Miller, L. L. \& Morton, J. J. (1950). Proc. Soc. exp. Biol., N.Y., 74, 218.

\section{Visual aids for teaching nutrition. By A. E. BENDER, Research Department, Bovril Ltd, 148 Old Street, London, E.C.I}

A set of fourteen charts has been prepared with the intention of providing classroom aids for the teacher of nutrition at a fairly elementary level. The principles of each subject are illustrated as far as possible as flow diagrams. The charts are designed to be used in conjunction with the lecture material in Manual of Nutrition (Ministry of Agriculture, Fisheries and Food, I955), from which most of the figures are taken.

Certain departures have been made from usual textbook practice. The usual approach to the $B$ vitamins is through their deficiency symptoms, beriberi and pellagra. It was considered more in keeping with newer knowledge to describe their positive function instead of their deficiency symptoms. Hence the B vitamins are 
dealt with in charts describing their functions as coenzymes and in the metabolic cycle. It was also thought that students of nutrition, even at an elementary level, should meet an enzyme.

As deficiencies of vitamins $A, E$ and $K$ are not likely to be met with in this country these vitamins are dealt with only in a comprehensive vitamin chart. Vitamin $\mathrm{D}$, calcium and phosphate are combined in one chart.

The fourteen charts comprise (I) Introduction, (2) Energy, (3) Carbohydrates, (4) Fats, (5) Proteins, (6) Digestion, (7) Enzymes and coenzymes, (8) Metabolic cycle, (9) Vitamin D, calcium and phosphate, (10) Vitamin C, (I I) Vitamin chart, (12) Blood, (I3) Water and salts and (r4) Meat.

\section{REFERENCE}

Ministry of Agriculture, Fisheries and Food (r955). Manual of Nutrition, 4th ed. London: H.M. Stationery Office.

\section{Copper sulphate and copper sulphide (CuS) as supplements for growing} pigs. By R. S. Barber, R. Braude, K. G. Mitchell and J. W. G. Porter, National Institute for Research in Dairying, Shinfield, Reading

The growth-promoting effect of the addition of 250 p.p.m. $\mathrm{Cu}$ as copper sulphate to a growing-pig diet, first reported by Barber, Braude, Mitchell \& Cassidy (1955), has since been widely confirmed, though the mode and site of action of copper are unknown. Preliminary studies with copper sulphide indicated that, whereas copper in this form had some growth-promoting effect, it differed from the sulphate in that it did not increase liver-copper stores, nor did it appear to reduce the faecal fungi count. If these observations were confirmed they might prove useful in studies on the mode of action of copper in promoting growth, and point to copper sulphide as the supplement of choice in practical rations.

In the present experiment the effect of $25^{\circ}$ p.p.m. $\mathrm{Cu}$ added to the basal diet either as copper sulphate or as copper sulphide was investigated with groups of pigs on experiment from 9 weeks of age to bacon weight. An additional group received 62.5 p.p.m. Cu as copper sulphide. The basal meal used and method of feeding were as described by Allen, Barber, Braude \& Mitchell (1958). Each group comprised twelve individually fed pigs, selected on the basis of litter origin, initial weight and sex.

Whereas the growth-promoting effect of copper sulphate was again confirmed, neither level of copper sulphide had a significant effect on the performance of the animals. As previously reported, stores of copper in the liver and kidneys were significantly increased when copper was given as sulphate, but no increase was found when the sulphide was given. Subsequently Bowland, Braude, Chamberlain, Glascock \& Mitchell (unpublished) showed that some labelled $\mathrm{Cu}$ was absorbed by pigs given labelled copper sulphide, although much more was taken up when the same amount of copper was given as sulphate. It would now appear that the effectiveness of copper in promoting growth is related to its solubility in the gut, but whether the site of action is systemic, enteric or both remains unknown. 
Data on total and dry-matter weight of liver, kidneys, spleen and heart, copper content of these organs and of samples of psoas muscle and back fat, and on overall carcass quality will be presented.

\section{REFERENCES}

Allen, M. M., Barber, R. S., Braude, R. \& Mitchell, K. G. (1958). Proc. Nutr. Soc. 17, xii. Barber, R. S., Braude, R., Mitchell, K. G. \& Cassidy, J. (r955). Chem. \& Ind. p. 6oI.

The incidence of pressure waves in the rumen of cattle. By A. T. Phillipson, Rowett Research Institute, Bucksburn, Aberdeen, and C. S. W. ReID, The Plant Chemistry Division, D.S.I.R., Palmerston North, New Zealand

Systematic analysis of records of the pressure changes in the dorsal and ventral sacs of the rumen of cattle obtained via a rumen fistula (Reid, Melville \& Cornwall, 1960) show that four major patterns occur between successive biphasic contractions of the reticulum. These are: ( $\mathrm{I}$ ) a wave of increased pressure in the dorsal sac (D), which always starts during the second contraction of the reticulum but is followed by no further pressure change; (2) the dorsal-sac pressure wave followed by a ventral-sac pressure wave (DV); (3) the dorsal-sac wave, then a second dorsal-sac wave, usually accompanied by a brief pressure spike in the ventral sac, followed by a ventral-sac wave (DSV); and (4) as for (3) except that the first dorsal-sac wave is also followed by a ventral-sac wave (DVSV). These categories account for about $90 \%$ of the changes observed in four cows and their incidence (Table $\mathrm{r} a$ ) was clearly related to the activity of the animals.

Table I. Incidence $(\%)$ of pressure waves in the rumen

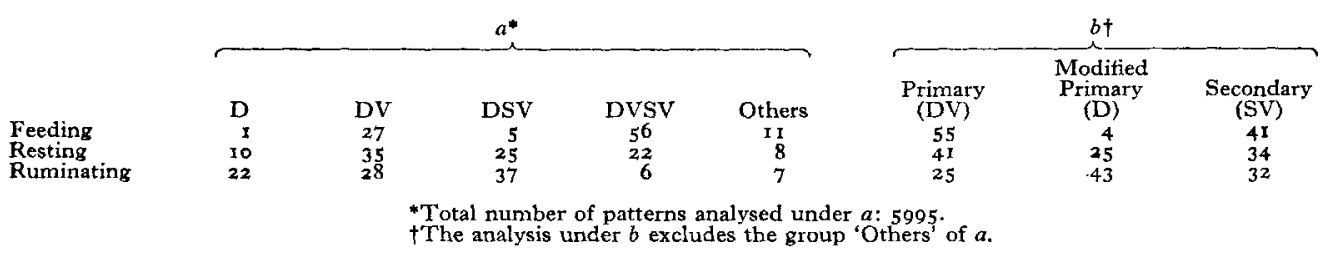

Ventral-sac pressure waves were least frequent during rumination. This is best shown when the categories are rearranged into 'primary' (DV), modified 'primary' (D) and 'secondary' (SV) sequences (Table $\mathrm{I} b$ ). Eructation was usually but not invariably associated with the second dorsal-sac wave which corresponded to the 'extra' ruminal contraction of Weiss (I953).

The pressure changes in the dorsal blind sac were not related to those of the main dorsal sac in a simple way but the changes in the ventral blind sac resembled the changes occurring in the main ventral sac, although more activity of the walls and pillars occurs than is reflected in the pressure changes recorded. The overall incidence of movement of the blind sacs was again related to the activity of the animal. These observations do not contradict but augment those of Wester (1926) and Schalk \& Amadon (1928). 
Reid, C. S. W., Melville, A. W. \& Cornwall, J. B. (1960). N.Z. F. agric. Res. 3, 41.

Schalk, A. F. \& Amadon, R. S. (1928). Bull. N. Dak. agric. exp. Sta. no. 2 I6.

Wester, J. (1926). Die Physiologie und Pathologie der Vormagen beim Rinde. Berlin: Julius Springer.

Weiss, K. E. (1953). Onderstepoort F. vet. Res. 26, $25 \mathrm{I}$.

Xanthine oxidase in human milk. By E. C. Owen, Hannah Dairy Research Institute, Kirkhill, Ayr and F. E. Hytten, Obstetric Medicine Research Unit (Medical Research Council), University of Aberdeen

It has long been believed that xanthine oxidase (XO) does not occur in human milk and some samples tested by Modi, Owen \& Proudfoot (1959) confirmed us in that belief until Bradley \& Gunther (1960) found XO in human milk of the 3 rd day post partum but not in earlier milk and in rapidly diminishing titre in later milk. Bradley \& Gunther's observation caused us to test further samples of human milk from the same maternity ward as that from which our earlier samples had come. Like Bradley \& Gunther we found that there was XO in maximum amount in milk of the 3 rd day. Kiermeier \& Capellari (1958) found large changes in the XO content of cow's milk with advancing lactation, and Owen \& Proudfoot (unpublished) found a large seasonal variation in $\mathrm{XO}$ in milk from individual cows, but unlike Kiermeier \& Capellari they were unable to attribute this variation to a simple effect of molybdenum intake though the variation probably depended on as yet unspecified dietary causes. We have thus, as did earlier workers quoted by Kiermeier \& Vogt (1957), encountered human milk both with and without $\mathrm{XO}$ and it would seem a hypothesis worthy of study that XO in human milk, like XO in the tissues of the rat, is under dietary control. Results of recent studies will be presented at the meeting.

\section{REFERENCES}

Bradley, P. I. \& Gunther, M. (1960). Biochem. F. 74, I5 P.

Kiermeier, F. \& Capellari, K. (I958), Biochem. Z. 330, ı6o.

Kiermeier, F. \& Vogt, K. (1957). Z. LebensmittUntersuch. 105, 194.

Modi, V. V., Owen, E. C. \& Proudfoot, R. (1959). Proc. Nutr. Soc. I8, i.

\section{Leakage of bone marrow and the consequent staining of the legs of broiler carcasses during storage at various frozen and chill temperatures. By D. H. Shrimpton, Low Temperature Research Station, Downing Street, Cambridge}

When young chicken are cooked after frozen storage the bones are sometimes darkened as a result of damage during freezing to the cells of both the marrow and the matrix of the young bone (Brant \& Stewart, 1950); the muscle on the legs may also be stained. Partial pre-cooking can prevent this seepage of marrow, but the conditions for success are critical (Ellis \& Woodroof, r 959).

The influence of different temperatures of freezing, frozen storage and chill storage $\left(0-5^{\circ}\right)$ on the occurrence of staining is reported here and R. W. Hocken will 
describe (to be published) the incidence and severity of these stains and the influence on them of sex and age in the rapidly growing broiler.

One hundred and forty-four frozen eviscerated broilers were randomized into three constant-temperature rooms maintained at $-10^{\circ},-20^{\circ}$ and $-30^{\circ}$. Three broilers of comparable weight were removed from each room weekly for 8 weeks. These carcasses were rapidly thawed $(<20 \mathrm{~min}$ ) roasted and dissected.

At the end of the rst, $4^{\text {th }}$ and 8 th weeks six additional carcasses were removed from each room, thawed rapidly and then held at $+5^{\circ}$. Also, at the end of the 8 th week, nine more carcasses were removed from each of the rooms, held at $-20^{\circ}$ and $-30^{\circ}$ and, after rapid thawing, held at $+\mathrm{I}^{\circ}$. The results are summarized in Table $\mathrm{I}$.

\section{Table I}

$\begin{array}{ccc}\begin{array}{c}\text { Method of } \\ \text { freezing }\end{array} & \begin{array}{c}\text { Temperature } \\ \text { of freezing } \\ \text { medium } \\ \left({ }^{\circ} \mathrm{C}\right)\end{array} & \begin{array}{c}\text { Temperature } \\ \text { of frozen } \\ \text { storage } \\ \left({ }^{\circ} \mathrm{C}\right)\end{array} \\ \begin{array}{c}\text { Commercial } \\ \text { air blast }\end{array} & -26 & -10 \\ \text { freezer } & & -20 \\ \begin{array}{c}\text { Immersion in } \\ \text { liquid nitrogen }\end{array} & -195.8 & -30 \\ & & \end{array}$
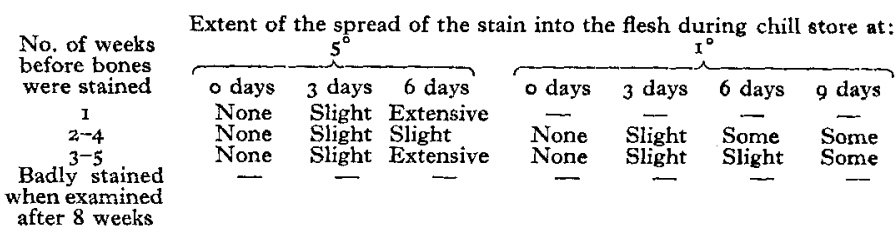

It has been shown that staining is a consequence of freezing which cannot be avoided even when the rate of freezing is so rapid that it is almost instantaneous. On bones, the intensity of the stain develops during frozen storage, but no stain spreads to the flesh until the carcasses are thawed.

\section{REFERENCES}

Brant, S. W. \& Stewart, G. F. (1950). Food Tech., Champaign, 4, 168. Ellis, C. \& Woodroof, J. G. (1959). Food Tech., Champaign, 13, 533.

Some effects of dietary sucrose in experimental protein deficiency. By

I. Macdonald and E. M. Gharavi, Department of Physiology, Guy's Hospital Medical School, London, S.E.I

The relative excess of carbohydrate in the diet is an important aetiological factor in kwashiorkor. Protein deficiency is also present in kwashiokor as it is in the clinically different condition of marasmus and it is possible that some of the differences between kwashiorkor and marasmus may be due to the relative carbohydrate excess in the pre-kwashiorkor diet. Some evidence to support this has been reported in pigs (Heard, Platt \& Stewart, 1958). To study the influence of various levels of sucrose in a diet low in protein rabbits were given diets so that in a group of animals of similar weight each ate the same amount of protein daily but the amount of carbohydrate differed. This meant that some animals in the group had a reduced calorie (and carbohydrate) intake compared with others.

The results showed that animals having a relative excess of dietary carbohydrate lost weight more rapidly, their livers at post-mortem were a smaller proportion of the initial body-weight, and there was a higher percentage of fat in the liver of these 
animals compared with those whose diet was inadequate in calories due to the reduced amount of sucrose in their food.

Total serum proteins were estimated in each animal at fortnightly intervals and these showed a more rapid fall in those on the higher-sucrose diets. The rate of fall in serum protein appeared to be related to the mean daily consumption of sucrose.

Serum electrophoresis showed a more marked fall in the albumin, $\alpha$-globulins and $\beta$-globulin fractions in the animals on high dietary sucrose intake. The $\gamma$-globulins, however, were higher in those animals on the low-sucrose diet.

Rabbits on normal stock green food and having a diet isocaloric with that containing the largest proportion of sucrose showed no alteration in the serum proteins or liver.

These experiments in rabbits on diets which may be compared to kwashiorkor on the one hand and marasmus on the other, show that the presence of an excess of sucrose, in a diet that is low in protein, seems to aggravate the protein deficiency and the extent of the changes in serum proteins and liver lipid is related to the amount of sucrose consumed.

\section{REFERENCE}

Heard, C. R. C., Platt, B. S. \& Stewart, R. J. C. (1958). Proc. Nutr. Soc. 17, xli.

The voluntary food intake of sheep. By K. L. BLAXTER, F. W. WAINMAN and R. S. Wilson, Hannah Dairy Research Institute, Kirhill, Ayr

On the basis of experiments with rats and experience with man, it is usually acceded that animals regulate their voluntary food intake according to energy needs, and eat more of rations of low energy value than of high. This is also true of poultry Bolton (1959). Experiments have been made with sheep in which dry fodders varying in apparent digestibility from 45 to $74 \%$ have been given to sheep as sole food. Between sheep of different sizes, the voluntary intake of a particular feed was found to vary with body-weight raised to the power $0.7 \pm 0.1$, and for this reason all results have been expressed on the basis of metabolic body size, W ${ }^{0.734}$ (Brody, 1945). The mean results for fifteen sheep are given in the Table.

Apparent digestibility of dietary energy, voluntary intake of dry food, intake of digestible energy and resultant gains in body-weight of sheep

\begin{tabular}{|c|c|c|c|c|}
\hline & $\begin{array}{c}\text { Apparent } \\
\text { digestibility of } \\
\text { energy } \\
(\mathrm{kcal} / 100 \mathrm{kcal})\end{array}$ & $\begin{array}{c}\text { Voluntary } \\
\text { intake of } \\
\text { dry matter } \\
\text { (g/kg W } \text { W.734 }^{0.75}\end{array}$ & 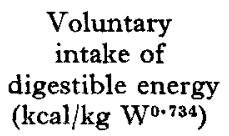 & $\begin{array}{c}\text { Daily gain in } \\
\text { weight } \\
\left.\text { (g/kg } W^{0.784}\right)\end{array}$ \\
\hline $\begin{array}{l}\text { Poor hay } \\
\text { Super hay } \\
\text { Dried grass }\end{array}$ & $\begin{array}{l}44 \cdot 7 \\
58 \cdot 8 \\
74 \cdot 2\end{array}$ & $\begin{array}{l}50 \cdot 5 \\
77 \cdot 2 \\
94.0\end{array}$ & $\begin{array}{l}101 \cdot 9 \\
206 \cdot 3 \\
318 \cdot 9\end{array}$ & $\begin{array}{r}-1.5 \\
+6.2 \\
+11.4\end{array}$ \\
\hline $\begin{array}{l}\text { Standard error of } \\
\text { means }\end{array}$ & \pm 0.85 & \pm 4.30 & $\pm 12 \cdot 8$ & $\pm 2 \cdot 3$ \\
\hline
\end{tabular}

The results together with further observations on foods with apparent digestibilities of 39 and 79 show that in sheep voluntary food intake increased with the 
quality of the ration. Calculations from the data show that an increase in the digestibility of food by 5 percentage units from 50 to $55 \%$ increased the energy digested by $32 \%$ and the digested energy available above maintenance by $99 \%$.

The passage of the food through the gut was measured and it was found that the rates of passage increased with improvement in food quality. Calculation of the amounts of dry matter in the digestive tract or 'fill' by the method of Blaxter, Graham \& Wainman (1956) showed that this was the same for all the rations, suggesting that purely physical factors dominate the regulation of food intake by sheep.

\section{REFERENCES}

Blaxter, K. L., Graham, N. McC. \& Wainman, F. W. (1956). Brit. F. Nutr. ro, 69. Bolton, W. (1959). 7. agric. Sci. 52, 364.

Brody, S. (1945). Bioenergetics and Growth. New York: Reinhold Publishing Corporation.

Fat synthesis from glucose by sheep. By D. G. Armstrong, K. L. Blaxter and N. McC. Graham, Hannah Dairy Research Institute, Kirkhill, Ayr

It is thought (Lindsay, I959) that the ruminant animal absorbs little glucose from its gut when given rations of hay and concentrated food, but estimates vary from nil to $80 \mathrm{~g} / 24 \mathrm{~h}$. Experiments have been made to find the calorimetric efficiency for fat synthesis of glucose when given by rumenal infusion and also by abomasal infusion in which fermentation by rumenal micro-organisms is avoided. Six experiments were made with two sheep with rumen fistulas and nine experiments with three sheep with abomasal fistulas. In all the experiments the sheep were given basal rations of dried grass to induce fat deposition. The $24 \mathrm{~h}$ energy exchange and retentions of carbon and nitrogen were determined using the apparatus of Blaxter, Graham \& Rook (1954), both when the basal ration was given and when sugar was added to it to supply 450,700 or $900 \mathrm{kcal} / 24 \mathrm{~h}$.

\section{The calorimetric efficiency of fat synthesis from glucose}

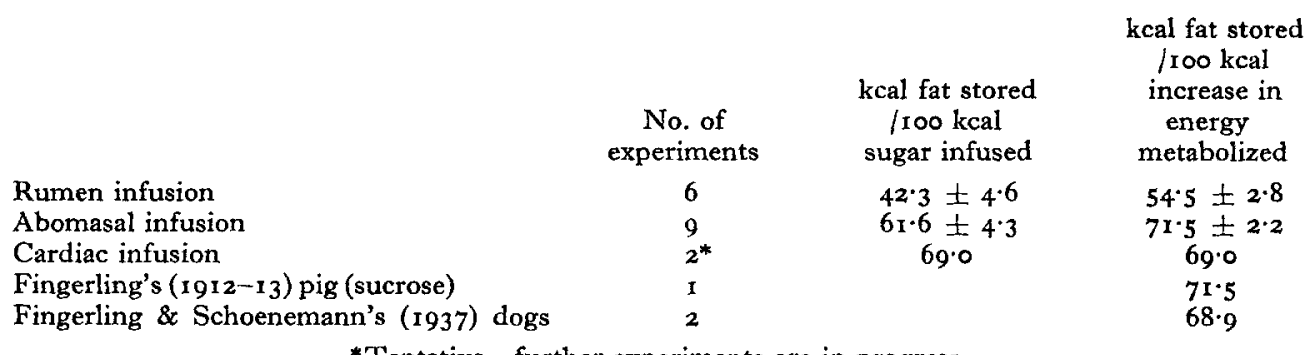

*Tentative-further experiments are in progress.

The results are given in the table. When glucose was given by rumenal infusion, the efficiency of utilization/kcal sugar given was $42 \cdot 3 \%$ and by abomasal infusion, $6 \mathrm{I} .6 \%$. The heat of combustion of the faeces increased with both methods of administration. Methane production rose by $2.37 \mathrm{kcal} / 100 \mathrm{kcal}$ sugar when the sugar 
was given by rumen, but by only $0.038 \mathrm{kcal} / \mathrm{I}$ oo kcal sugar when it was given by abomasum. When the increment of energy retained is expressed on the basis of the increment in energy metabolized, sugar infused into the rumen gave an efficiency of $54.5 \%$ and into the abomasum of $71.5 \%$. The latter figure is in agreement with results obtained with simple-stomached animals given glucose or sucrose. The lower value for glucose infused into the rumen suggests that fermentation of glucose to steam-volatile fatty acids leads to a less efficient utilization even when the energy lost as methane is discounted. Preliminary measurements of fat synthesis from glucose given by cardiac infusion show that abomasal utilization of the sugar is the same as that obtained when glucose enters the blood stream directly.

\section{REFERENCES}

Blaxter, K. L., Graham, N. McC. \& Rook, J. A. F. (1954). F. agric. Sci. 45, io.

Fingerling, G. (1912-13). Landw. VersSta. 84, I49.

Fingerling, G. \& Schoenemann, R. (1937). Landw. VersSta. x27, 157.

Lindsay, D. B. (1959). Vet. Rev. Annot. 5, 103.

The effect of dietary additions of amino acids on nitrogen retention in young pigs. By A. S. Jones and W. R. Hepburn, Rowett Research Institute, Bucksburn, Aberdeen

A diet providing $15 \%$ crude protein and $86 \%$ dry matter, consisting of $70 \%$ ground barley, $10.5 \%$ wheatings and the rest of its protein from $10.5 \%$ expeller decorticated groundnut meal was supplemented with L-lysine monohydrochloride and/or DLmethionine. The four diets, which were equalized for crude-fibre content with oatfeed and provided adequate amounts of all known vitamins and $0.3 \%$ Aurofac, together with a control diet containing white-fish meal, were fed to ro Landrace $\times$ Wessex pigs of initial weight $25 \mathrm{lb}$ according to a type of balanced incomplete block design. The daily rate of feeding was $5 \%$ of the live weight at the commencement of each ro-day test period. The procedure was repeated using diets providing either 12,18 , or $21 \%$ crude protein. The total digestible nutrients in all diets were maintained at $70 \%$.

Supplements were added so that the concentrations of the amino acids concerned were equal to those in the control diet at the same level of crude protein.

The results shown in Fig. $\mathrm{a} a$ indicate a highly significant response to L-lysine at all levels of crude protein. At $18 \%$ and $21 \%$ crude protein the lysine supplement failed to give nitrogen retentions equivalent to those obtained on the fish controls, even when further supplemented with DL-methionine. Maximum nitrogen retention on the control diet, and on diets supplemented with L-lysine alone or together with DL-methionine occurred at $18 \%$ crude protein while on the remaining diets the highest retention was at $21 \%$ crude protein.

As shown in Fig. I $b$, no response was obtained to DL-methionine, except at $18 \%$ crude protein when it significantly depressed percentage nitrogen retention. Maxi- 

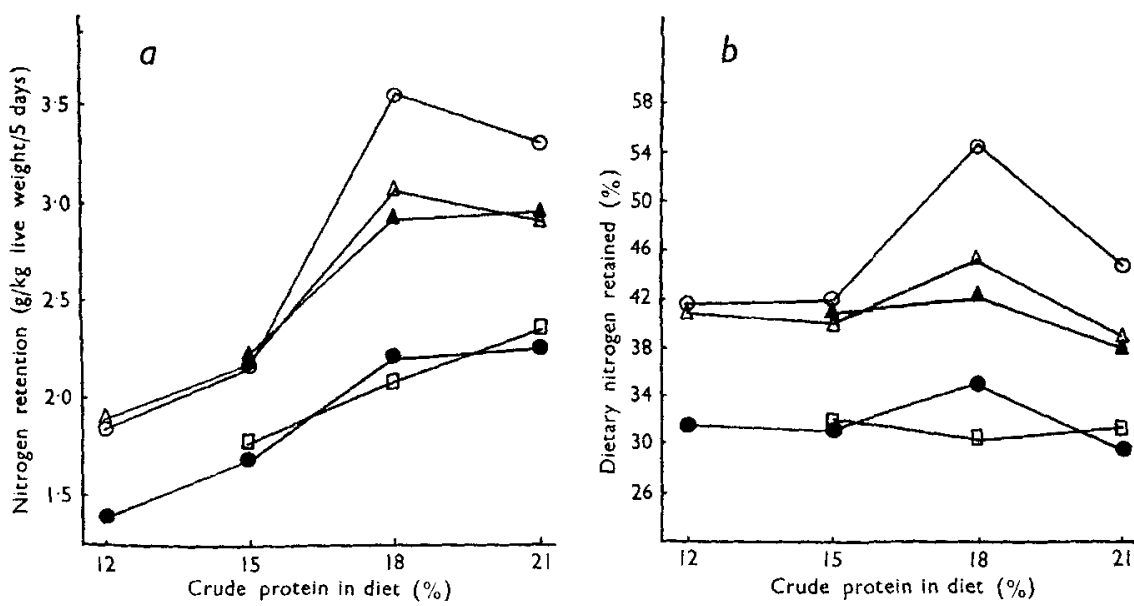

$O$, fish meal;

$\square$, groundnut + methionine;

$\Delta$, groundnut + lysine;

Fig. 1a. Influence of protein level and amino-acid supplements on nitrogen retention per $\mathrm{kg}$ body-weight.

Fig. 1b. Influence of protein level and amino-acid supplements on percentage nitrogen retention.

(Each point is the mean of six 5-day balance measurements on unrelated pigs.)

mum percentage nitrogen retention for all diets was obtained at $18 \%$ crude protein, except for the diet containing groundnut meal supplemented with methionine alone.

\section{Rheumatoid-like joint lesions in guinea-pigs with chronic partial vitamin \\ G deficiency. By E. Kodicek, Dunn Nutritional Laboratory, University of Cambridge and Medical Research Council}

A partial prolonged deficiency of vitamin $\mathrm{C}$ was induced in 108 guinea-pigs given, after 10 days of deficiency, daily supplements of $0.5^{-1} \mathrm{mg}$ ascorbic acid. Fifty-five animals developed in the $4^{\text {th }}$ to $5^{\text {th }}$ week of partial deficiency a swelling of one or both knee joints which resulted eventually in complete ankylosis, while controls receiving $10 \mathrm{mg}$ ascorbic acid/day were not affected. The arthritis was not caused by scorbutic haemorrhages or bony lesions, but in many respects resembled that of human rheumatoid arthritis. A hyperplasia of the synovial membrane was noted together with hyperplastic connective tissue packing around the joint and thickening of its capsule, causing immobilization of the joint. The articular surfaces appeared normal except that a periodate-Schiff's positive fibrinoid was deposited on the synovial membranes and lymphatic foci appeared in the thickened villi. Eventually, a true fibrous ankylosis of the joint developed, with complete destruction of the articular surfaces as described previously (Murray \& Kodicek, 1949). Treatment with cortisone acetate (COA) (Io $\mathrm{mg} /$ day) reduced the swelling, but did not improve the movements, or the histological picture. Ascorbic acid, administered at this stage, had no effect. Preventive daily injections of $5 \mathrm{mg}$ COA for 20 days appeared to protect animals from occurrence of the joint lesions, while daily injections of $3 \mathrm{mg}$ deoxycorticosterone acetate (DOCA) appeared to increase the incidence. 
The greatly enlarged adrenals of the deficient animals with joint lesions, showed extensive damage of the zona fasciculata, with grossly extended capillaries. The adrenals of COA-treated animals were of normal size and histological appearance. Treatment with DOCA did not change the abnormal histological picture.

It is suggested that the joint lesions are due to an indirect effect of deficiency, which, acting as stress factor (Perič-Golia, Eik-Nes \& Jones, 1960), damages first the adrenals, which in turn may cause, by impaired cortical secretion, the lesions in the joints. The pathological changes resemble those observed in anaphylactic arthritis (Coburn, Graham \& Haninger, I954; Jones \& Carter, 1954) and in arthritis induced by adrenal damage (Harrison \& Barnett, 1953).

\section{REFERENCES}

Coburn, A. F., Graham, C. E. \& Haninger, J. (1954). F. exp. Med. 100, 425.

Harrison, R. G. \& Barnett, T. J. (1953). Ann. Rheum. Dis. 12, 275.

Jones, R. S. \& Carter, Y. (1954). Arch. Path. 58, 613.

Murray, P. D. F. \& Kodicek, E. (1949). F. Anat. 83, 158.

Peric-Golia, L., Eik-Nes, K. \& Jones, R. S. (1960). Endocrinology, 66, 48.

\section{Correlation of albumin and vitamin $A$ in the serum of protein-malnourished}

pigs. By C. J. Friend, C. R. C. Heard, B. S. Platt, R. J. C. Stewart and M. R. TURNER, Human Nutrition Research Unit, Nutrition Building, National Institute for Medical Research, The Ridgeway, Mill Hill, London, N.W.7

The serums of protein-deficient pigs (Heard, Platt \& Stewart, 1958) were examined for vitamin $A$ and proteins and their livers for vitamin A. The pig serum 'albumin' fraction was determined by paper electrophoresis.

The serum vitamin A level was not dependent on the liver stores of the vitamin, but showed a close correlation with the serum albumin (see Fig.). Two pigs, one fed

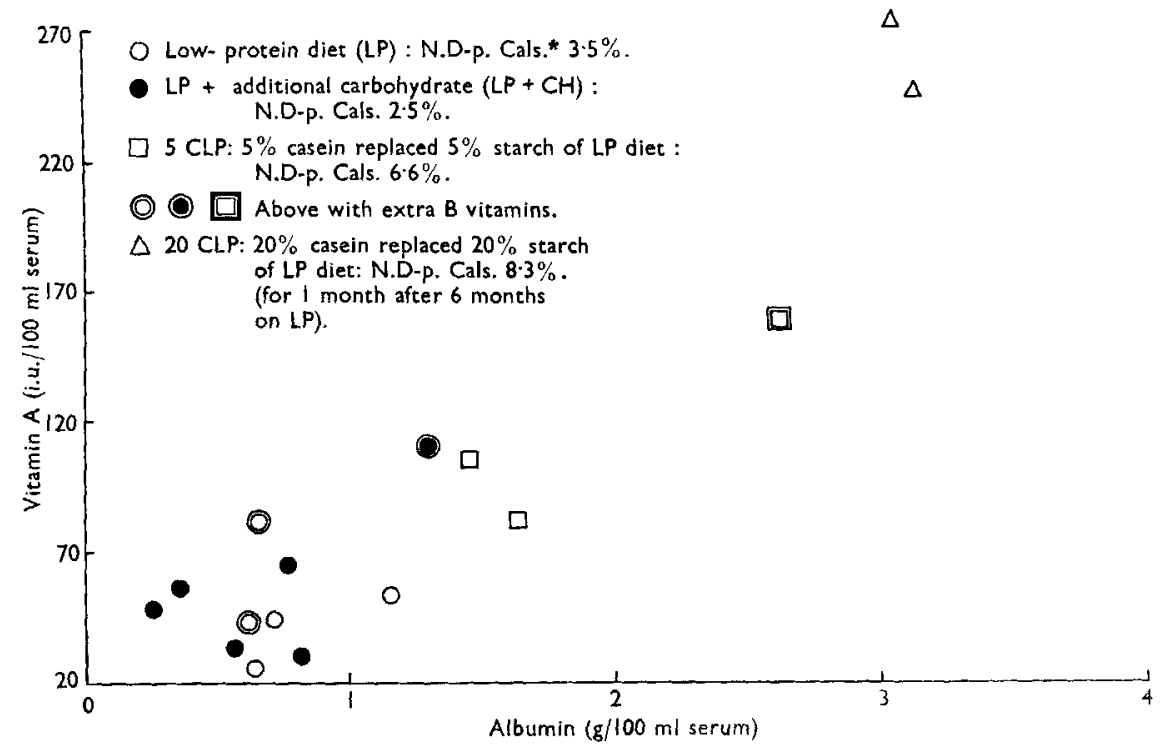


on a high- and the other on a low-protein diet, had identical concentrations of the vitamin in their livers (43 i.u./g): they had 2.66 and $0.57 \mathrm{~g}$ albumin and $\mathrm{I}_{5} \mathrm{O}$ and 33 i.u. vitamin $\mathrm{A} / \mathrm{r} 00 \mathrm{ml}$ serum, respectively. Furthermore, whilst a high dose $(200000$ i.u.) of vitamin A given orally increased the liver store of protein-deficient pigs by 200 i.u./g liver, it had no effect on the serum vitamin A. On the other hand, the serums of protein-deficient pigs recovering on a diet of enhanced protein content showed increased amounts of both albumin and vitamin.

The association of signs of vitamin A deficiency with protein malnutrition in human subjects eating foods of mainly vegetable origin may be due to poor absorption (Trowell, Moore \& Sharman, 1954; Scrimshaw, Behar, Arroyave, Viteri \& Tejada, 1956) and/or impaired conversion of carotene. We conclude that a more important factor is the low serum 'albumin', which reduces the transport of vitamin A from the liver, where stores may be adequate, by restricting production of the water-soluble 'albumin'-vitamin A complex of plasma.

\section{REFERENCES}

Heard, C. R. C., Platt, B. S. \& Stewart, R. J. C. (1958), Proc. Nutr. Soc. 17, xli.

Miller, D. S. \& Platt, B. S. (1959). Proc. Nutr. Soc. 18, vii.

Scrimshaw, N. S., Behar, M., Arroyave, G., Viteri, F. \& Tejada, C. (r956). Fed. Proc. 15, 977.

Trowell, H. C., Moore, T. \& Sharman, I. M. (1954). Ann. N.Y. Acad. Sci. 57, 734.

\section{Glycogen and glucose-6-phosphatase in the liver of normal and protein-} deficient pigs. By Pamela A. J. Durbin, C. R. C. Heard and B. S. PlatT, Human Nutrition Research Unit, Nutrition Building, National Institute for Medical Research, The Ridgeway, Mill Hill, London, N.W.7

In pigs the accumulation of glycogen in the liver is as characteristic a feature of protein deficiency as is the deposition of fat which has hitherto engaged the attention of so many investigators, particularly of protein malnutrition in the human subject. This glycogen is not readily available for correcting hypoglycaemia (Stewart \& Heard, 1959). It seemed possible that this might be due to lack of glucose-6phosphatase (G6P-ase) in the liver.

Pigs were fed from I I days of age on $(a)$ a commercial diet $(\mathrm{N})$; $(b)$ a $5 \%$ vegetableprotein diet (LP); (c) LP with $5 \%(\mathrm{w} / \mathrm{w})$ of casein replacing starch (CLP). Some animals received additional carbohydrate $(+\mathrm{CH})$ between meals of LP or CLP diet. The animals were fasted $\mathrm{x} 8 \mathrm{~h}$ before killing. Portions of the liver were rapidly removed, frozen in solid carbon dioxide and stored at $-20^{\circ}$ until analysed for glycogen (Good, Kramer \& Somogyi, 1932), G6P-ase activity (Freedland \& Harper, 1958) and for fat and water content.

Liver G6P-ase activity is influenced by many hormonal and dietary factors (Ashmore \& Weber, 1959), but no report has been found of its virtual absence in severe protein deficiency. G6P-ase activity is negligible in the II-day-old pig's liver; on the LP and $\mathrm{LP}+\mathrm{CH}$ diets the enzyme fails to develop; the addition of $5 \%$ casein to these diets allows normal enzyme synthesis to proceed and also improves 
Composition and enzyme activity of pigs' livers expressed in terms of glycogen-andfat-free dry weight

Diet (g/day)

No. of animals

Age (days)

Water $(\mathrm{g} / 100 \mathrm{~g})$

Fat $(\mathrm{g} / \mathrm{I} / \mathrm{g} \mathrm{g})$

Glycogen $(\mathrm{g} / \mathrm{1}$ oo $\mathrm{g})$

G6P-ase (moles P) $\min / 100 \mathrm{~g})$

$\begin{array}{ccccc}\text { N } & \mathrm{N} & \mathrm{N} & \text { CLP } & \text { CLP } \\ \text { ad lib. } & \text { ad lib. } & \text { ad lib. } & \text { ad lib. } & (250) \\ \text { I } & \mathrm{I} & 7 & \mathrm{I} & \mathrm{I} \\ \mathrm{I} \mathrm{I} & 20 & 26-8 \mathrm{I} & 66 & 66 \\ 360 & 359 & 336 & 421 & 309 \\ \mathrm{I} 4 & 13 & 9 & 8 & 4 \\ 0.2 & 2 & 6 & 14 & 28 \\ 0.1^{*} & 5.8 & 4.6 & 7.9 & 4.3\end{array}$

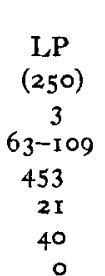

LP (250)

$+$ $\mathrm{CH}(75)$ 3
$64-102$ 572

75

60

$0.54^{*}$

* These figures are at the limits of sensitivity of the method and indicate little or no G6P-ase activity.

the pig's ability to mobilize liver glycogen. Lack of G6P-ase in the liver may therefore help to explain both the failure of animals on protein-deficient diets to recover readily from hypoglycaemia induced by insulin and the spontaneous hypoglycaemia of baby pigs.

\section{REFERENCES}

Ashmore, J. \& Weber, G. (1959). Vitam. छ Horm. I7, 9 I.

Freedland, R. A. \& Harper, A. E. (1958). F. biol. Chem. 233, I.

Good, C. A., Kramer, H. \& Somogyi, M. (r932). F. biol. Chem. roo, $4^{8} 5$.

Stewart, R. J. C. \& Heard, C. R. C. (1959). Proc. Nutr. Soc. x8, x.

The relation between net protein utilization (N.P.U.) and protein : calorie ratio. By D. S. Miller and P. R. PAyne, Human Nutrition Research Unit, Nutrition Building, National Institute for Medical Research, The Ridgeway, Mill Hill, London, N.W.7

The various attempts, exemplified by FAO (1957) to predict protein values, have not taken into account alterations of N.P.U. with changes in protein concentration in the diet; some success has been achieved in predicting N.P.U. at low levels of nitrogen intake from protein scores based on amino-acid analysis, but when practical diets are considered it has been shown that net protein utilization operative (N.P.U. (op) -Platt \& Miller, I959) is not directly related to the amino-acid content (Drury \& Miller, 1959), and that this can lead to considerable errors in prediction.

For maintenance, rats are found to need a diet having a net dietary-protein calories (N.D-p. Cals) of $4 \%$ and it is proposed that net protein utilization standardized (N.P.U.(st)-Miller \& Payne, unpublished) be determined at this level. Above maintenance, the relationship between N.P.U.(op) and the protein : calorie ratio has been investigated using diets containing varying levels of three different proteins, and a general equation has been derived which describes this. 
Vol. I9

Thus N.D-p. Cals. $=$ N.P.U.(op) $\times P$

$$
=\text { N.P.U.(st) } \times P \frac{54-\mathrm{P}}{54-\mathrm{P}_{\mathrm{M}}} \text {. }
$$

$\mathrm{P}=$ protein calories as percentage of total calories,

$\mathrm{P}_{\mathrm{M}}=$ protein calories as percentage of total calories required for maintenance

$$
=\frac{4}{\text { N.P.U.(st) }} \text {. }
$$

\section{REFERENCES}

Drury, E. A. \& Miller, D. S. (1959). Proc. Nutr. Soc. 18, xxvi.

FAO (1957). F.A.O. nutr. Stud. no. 16.

Platt, B. S. \& Miller, D. S. (1959). Proc. Nutr. Soc. 18, vii.

A nomogram for the prediction of the protein value of diets. By D. S. MilleR and P. R. PAYNe, Human Nutrition Research Unit, Nutrition Building, National Institute for Medical Research, The Ridgeway, Mill Hill, London, N.W.7

The figure shows the relationship between the protein : calorie ratio, N.P.u.(st) or 'protein score', and N.D-p. Cals.

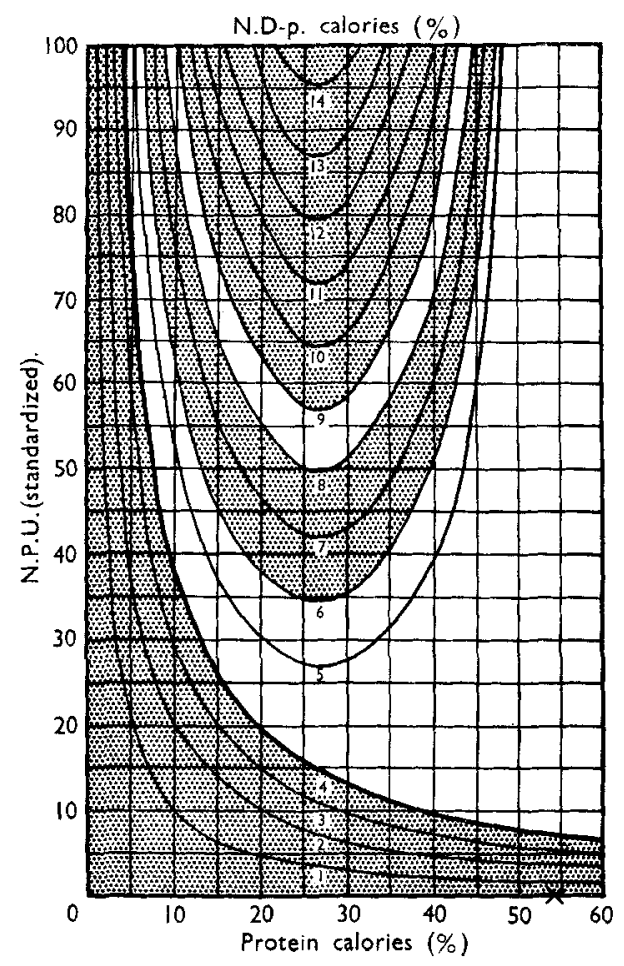


Given an estimate of N.P.U.(st), either directly by rat assay, or from chemical data, it is possible to read off N.D-p. Cals. Below maintenance (i.e. the region on the nomogram below the hyperbola N.D-p. Cals. $\%=4$ ) N.P.U. is constant, i.e. N.P.U.(op) $=$ N.P.U.(st). Above maintenance N.P.U.(op) falls with increase in protein concentration; the extent of this fall may be obtained from the nomogram by laying a ruler from that point on the hyperbola N.D-p. Cals. $\%=4$ corresponding to the 'score' in question, to the point marked $\mathrm{x}$ on the protein-concentration axis. The lowest possible protein score, or alternatively, the lowest concentration of protein in a mixture required to achieve any given N.D-p. Cals. \%, may also be seen on the nomogram.

The effects of the addition of protein concentrates to diets may be predicted; of the two possible effects, firstly the raising of the concentration of protein in the diet, and secondly the improvement of the pattern of amino-acids, the former is the more important and may be obtained from the nomogram.

The abbreviations used in this communication are defined in the previous abstract:

\section{Glinical and cytological manifestations of protein malnutrition in the skin} of pigs. By K. O. Godwin, Human Nutrition Research Unit, Nutrition Building, National Institute for Medical Research, The Ridgeway, Mill Hill, London, N.W.7

This report is concerned with the skin of pigs suffering from syndromes resembling marasmus and kwashiorkor in human subjects. Hartwell ( 1955 ) has pointed out that, of all animals studied, only the pig has a skin structurally similar to the human. The experimental conditions under which these animals were reared have been presented elsewhere (Platt, 1958) and have been given to this Society (Heard, Platt \& Stewart, 1958).

On gross examination the skin appears dry, scaly, wrinkled and cracked; the hair is long, fine, dry and has an unkempt appearance. The animals on the low-protein diet with additional carbohydrate ( $\mathrm{LP}+\mathrm{CH}$ ) show the same types of changes though of greater severity than those fed on low-protein (LP) diets. Animals receiving the low-protein diet with $5 \%$ extra protein as casein (CLP) show mild changes but are nearer the normal.

Microscopic examination shows a progressive thinning of the epidermis in animals on normal, CLP, LP and LP + CH diets; the epidermis in animals on $\mathrm{LP}+\mathrm{CH}$ is often only one cell thick. There is a similar trend in the disappearance of the dermal papillae; in the LP + CH group they are almost absent. The keratin layer of the malnourished animals is puffed-up and flaky, consistent with the picture seen macroscopically. Staining with periodic acid-Schiff (PAS) reveals the presence of PAS-positive material on the surface of the skin, as in the skin of rats suffering from protein malnutrition (Godwin, 1956).

The dermis of the skin of the malnourished animals is disorganized; the collagen fibres are broken up; dermal spaces are abundant and the fibroblasts are shrunken. High-power examination reveals a foamy appearance of the collagen fibres. Again, 
there is a trend in the severity of these changes from the normal to the $\mathrm{LP}+\mathrm{CH}$ group. The interpretation of the changes described is complicated by the possibility that in protein malnutrition other dietary factors may not be available to the skin; for example, the evidence from the communication by Friend, Heard, Platt, Stewart $\&$ Turner (I960) suggests that the peripheral tissues may not be adequately supplied with vitamin $\mathrm{A}$.

\section{REFERENCES}

Friend, C. J., Heard, C. R. C., Platt, B. S., Stewart, R. J. C. \& Turner, M. R. (1960). Proc. Nutr. Soc, 19, xxxiv.

Godwin, K. O. (1956). A study of intercellular substances at varying levels of protein intake. Ph.D. thesis, University of London.

Hartwell, S. W. (1955). The Mechanisms of Healing in Human Wounds. American Lecture Series $25^{\circ}$. Springfield, Ill.: C. C. Thomas.

Heard, C. R. C., Platt, B. S. \& Stewart, R. J. C. (1958). Proc. Nutr. Soc. r7, xli.

Platt, B. S. (1958). Ann. Soc. belge Med. trop. 38, 425.

\section{Diurnal variations in venous-blood reducing sugar in ruminating calves.} By R. D. Noumbe and T. R. Preston, Rowett Research Institute, Bucksburn, Aberdeen

Five I2-week-old, early-weaned calves were fed a dry concentrate mixture (Preston, I957) at the daily rate of $80 \mathrm{~g} / \mathrm{kg}$ body-weight ${ }^{\mathbf{0}} \mathbf{7 4}$. Blood samples were taken hourly through a polythene catheter inserted in the jugular vein. Three series of samples were taken: (A) 8 a.m. to 7 p.m. on the Ist day, the calves being fed at 8.ro a.m.; (B) 7 p.m. on that day to 6 a.m. the following day, the calves being fed at 7.ro p.m.; and (C) 8 a.m. to 7 p.m. the following day when no food was given. Blood reducing sugar was determined by the method of Nelson (1944) with the copper reagent of Somogyi (1945). The results are given in Table $\mathbf{I}$.

Table I. Mean values for blood reducing sugar in five calves sampled at hourly intervals during three consecutive periods each of $12 h$

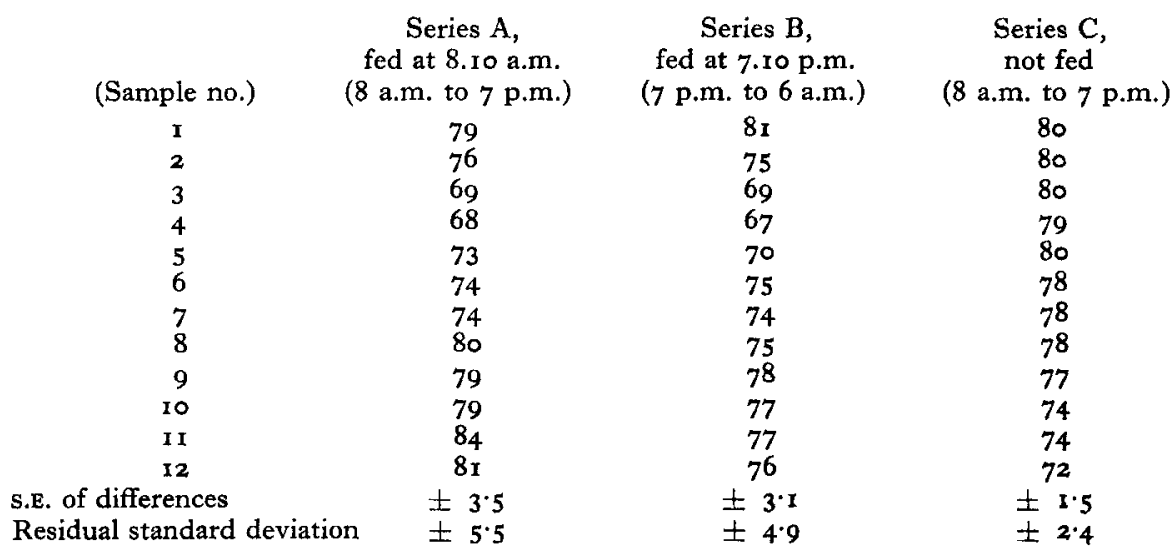

In series $A$ and $B$ there was a depression in blood-sugar level to a minimum value at about $4 \mathrm{~h}$ after feeding followed by a more gradual rise to values similar to those 
at the start. In series $\mathrm{C}$ the pattern was clearly different, the values being stable for the first $4 \mathrm{~h}$ and then decreasing gradually for the remainder of the period but at no time reaching a value as low as that attained in series $\mathrm{A}$ and $\mathrm{B}$. The residual variability in blood reducing sugar value, after allowing for animal differences and the average change with time, was higher for series $A$ and $B$ when the calves were fed, than for series $C$ when they were not fed $(P<0.001)$, but did not differ significantly between $\mathrm{A}$ and $\mathrm{B}$.

\section{REFERENCES}

Nelson, N. (1944). F. biol. Chem. 153, 375 .

Preston, T. R. (1957). N.A.A.S. quart. Rev. no. 35, p. 18.

Somogyi, M. (1952). F. biol. Chem. r95, 19. 